who is continuing the systematic work of his father on the specific heat of metals.

Keesom was known by his collaborators and friends as a severe but kindly director; he was always extremely helpful to young scientists and students. A. VAN ITTERBEeK

Brigadier J. A. Sinton, V.C., O.B.E., F.R.S.

John Alexander Sinton, who died on March 25, was born in British Columbia, of Ulster parents, on December 2, 1884. He was educated at the Royal Belfast Academical Institution and at The Queen's College, Belfast, where he was an exhibitioner. $\mathrm{He}$ graduated M.B., Ch.B., with first-class honours at the Royal University of Ireland in 1908, and after holding house appointments at the Royal Victoria Hospital, Belfast, became Riddell demonstrator in pathology at The Queen's University and clinical pathologist to the Ulster Eye, Throat and Ear Hospital and to the Mater Infirmorum Hospital. In 1911 he took the diploma of tropical medicine at Liverpool, and in the same year entered the Indian Medical Service.

During the First World War, Sinton served as a regimental medical officer in Mesopotamia and was awarded the Victoria Cross for most conspicuous bravery and devotion to duty during an action at Sheikh Sa'ed in 1916. He also received the Russian Order of St. George, and was mentioned in dispatches on four occasions. He was promoted brevet major in 1919 and saw further active service in Afghanistan and Waziristan, being again mentioned twice in dispatches and being appointed O.B.E. in 1921.

On reversion to civil employment in 1921, Sinton entered the Medical Research Department of the Indian Medical Service. He was in charge of the Quinine and Malaria Inquiry at Kasauli during 1921-30 and was director of the Malaria Survey of India from its foundation until 1936. He returned to England in that year, and in 1937 became Manson Fellow of the London School of Hygiene and Tropical Medicine and adviser on malaria to the Ministry of Health. He also carried out researches in the Malaria Laboratory, Horton. On the outbreak of the Second World War he was recalled to duty and, after a brief period in India, became consultant malariologist successively to the East African Forces, the Middle East Forces and the War Office. He finally retired in 1945 with the honorary rank of brigadier and settled down on a country estate at Cookstown in Northern Ireland. $\mathrm{He}$ took an active part in public affairs, being a justice of the peace and high sheriff for Tyrone.

Sinton's activities covered a wide field, but were principally concerned with the study of malariology in its various aspects. His researches on the chemo. therapy of the disease were of outstanding importance and he also published a number of papers on its immunology, parasitology, laboratory and survey techniques and sociological effects. Among his other interests was the study of cutaneous leishmaniasis, on which he published several articles. He was also the author of a series of thirty-six papers on Indian species of Phlebotomus, on which he was a leading authority.

Sinton was elected a Fellow of the Royal Society in 1946 and received a number of other honours. He was awarded the Arnott Memorial Medal of the Irish Medical Schools and Graduates Association in
1917 ; the Chalmers Memorial Medal of the Royal Society of Tropical Medicine and Hygiene in 1928; the Bisset-Hawkins Medal of the Royal College of Physicians of London in 1944 ; the Robert Campbell Memorial Medal of the Ulster Medical Society in 1946 ; the Mary Kingsley Medal of the Liverpool School of Tropical Medicine in 1949; and the Manson Medal of the Royal Society of Tropical Medicine and Hygiene in 1956, an award which was announced only a few days before his death.

Sinton was a man of boundless energy, high moral rectitude and outstanding personal charm. He never spared himself in any of his endeavours and was a source of inspiration to all who came in contact with him. He was buried with full military honours near his home in County Tyrone. G. Covers

\section{Dr. A. G. Lowndes}

Ashley Gordon Lowndes, who died on March 15 at Falmouth after an attack of pneumonia, has left his mark on science in several ways. His passion for investigation produced some valuable researches and, perhaps even more important, it generated in others a love of the subject and a rigour of method that have been the basis of many successful investigations. He went to sea in the Merchant Navy at the age of thirteen, until he was twenty-six, when the curate of a church in Portsmouth, where Lowndes was taking a Sunday School, recognized his brilliance as a teacher. The curate's father was the headmaster of Ardingley and he took Lowndes on to his staff. From there he went to Cambridge, where he was one of J. T. Saunders's first pupils and obtained a 'double first' and a 'swimming blue'. He joined the analytical staff of Nobel Industries as a chemist, and there his ideas led to several successful new processes.

The next phase of Lowndes's career was that Norwood took him to Marlborough as biology master, and it was here that he did his best work, both as teacher and investigator. He drove his pupils hard but gave them a real opportunity to see the fascination of living things and the possibility of exact investigation of them. It must be more than an accident that so many of them have proved to be successful investigators and teachers. His simple belief in scientific and moral principles, single-minded love of the subject and directness of statement, provided a compelling appeal to boys and an excellent basis for life.

Lowndes became interested at this time in Crustacea, and his series of paper.s on them are probably his best scientific work. He quickly mastered the systematics of the Entomostraca and contributed substantially to knowledge of freshwater copepods and ostracods. He would probably have been wise to concentrate on systematics, but it was characteristic of him to want to do more. By breeding experiments he showed that the superficially similar Leptocyclops speratus and agilis are unable to cross, although the various races of the latter do so freely. He then embarked on a study of locomotion and feeding, first in Chirocephalus, then in calanoids. $\mathrm{He}$ used elegant photographic techniques and obtained results that seemed to him unambiguous. But as he entered these experimental fields his aggressiveness led him into controversies of a type that often seemed unhappy; but were perhaps necessary for him. They became still more marked as he attacked more complicated problems, such as the mechanism 
of flagellar movement and the density of aquatic organisms. In such matters he usually had much of right on his side, but his simple approach sometimes let him down. The value of his work was recognized by the award of the Cambridge Sc.D.

He gave up his career at Marlborough to undertake research in a leper colony in West Africa, where he stayed for eighteen months. When asked why he had left he replied, "Well, it is obvious why the natives get leprosy and I told the authorities so, but they wouldn't listen to me. Since we have stopped them eating each other the only protein they get is an occasional snake".
After this he taught in a number of schools, though never with quite the same success as at Marlborough. He declared that of all the nine headmasters he had served under none could hold a candle to Norwood. $\mathrm{He}$ continued investigations on various biological and geological subjects, receiving much hospitality from the Marine Biological Association at Plymouth.

Lowndes carried always something of the sea about him, in his rolling gait, his simple directness and sharpness of observation. His influence will be felt by his pupils for more than one generation, and his contributions to knowledge of Crustacea may last even longer than that.
J. Z. YouNG

\section{NEWS and VIEWS}

\section{Directorship of the British Scientific Instrument} Research Association :

\section{Mr. A. J. Philpot, C.B.E.}

Mr. A. J. РнiLpot will retire in June from the directorship of the British Scientific Instrument Research Association, a post which he has held since 1937. Mr. Philpot had a distinguished academic career at King's College, London, and later, after active service in the First World War, at Cambridge in the Cavendish Laboratory under Lord Rutherford. In 1920 he joined the staff of the British Scientific Instrument Research Association soon after its foundation as the first of the co-operative industrial research associations to be established. As senior physicist of the Association he accomplished a large amount of experimental work, the results being recorded in publications and twenty-one research reports on subjects as varied as X-ray tubes, the stability of glasses, luminous compounds, thermometer liquids and the deposition by volatilization of reflecting surfaces on glass. In $1937 \mathrm{Mr}$. Philpot was appointed director of research and secretary of the Association, in succession to Dr. Harry Moore, and soon his responsibilities were greatly enlarged by the Second World War. In 1943 he was appointed chairman of the new Inter-Service Optical Instrument Committee which did vital co-ordinating work. Though the laboratories of the Association, in Russell Square, London, were damaged by a bomb, many firms new to instrument manufacture were helped to master the problems of design and production, and the end of the War found the Association with a greatly increased membership but quite inadequate laboratory space. New premises were found on the outskirts of London, new departments were established and new staff engaged, and Mr. Philpot found himself director of an organization which had multiplied its size by five in a couple of years. At the same time, he undertook new duties, being for a number of years director of the Scientific Instrument Manufacturers' Association, the trade association of the industry. Mr. Philpot has played an active part in the affairs of scientific societies concerned with physics and instruments, and has been vice-president and treasurer of the Physical Society, vice-president of the Institute of Physics, and vice-president of the Society of Instrument Technology.

Dr. J. Thomson

Dr. J. Thomson, who will succeed Mr. Philpot, is a graduate of the University of Glasgow, being awarded the Kelvin Medal of the University in 1932 for research in mathematical and experimental physics. $\mathrm{He}$ lectured in physics at the Universities of Reading and Glasgow until the end of 1939, when he joined the Admiralty Signal School at Portsmouth. During the Second World War he was engaged in research on microwave devices, and his work included service with a Royal Marine Commando Unit throughout the German campaign. After the War he was appointed professor of physics and electrical engineering in the Royal Naval College, Greenwich, and later he became the deputy director of physical research (C.V.D.) at the Admiralty with responsibility for research and development in the field of electronic valves on behalf of the three Armed Services. Last year he also undertook the editorship of the new Journal of Electronics. His published work includes three books and many research papers.

\section{Presidency of the Society of Glass Technology : Dr. J. H. Partridge}

Ar the annual general meeting of the Society of Glass Technology, held in Sheffield on April 25, Dr. J. H. Partridge was elected president, in succession to Sir Graham Cunningham, who has retired after serving for two years. Dr. Partridge graduated in metallurgy from the University of Birmingham in 1924, and four years later joined the Research Laboratories of the General Electric Co., Ltd.; he is now head of the Company's Glass, Refractories and Ceramics Department. He has published more than thirty papers on studies relating to metals, glass and refractories and is the author of "Refractory Blocks for Glass Tank Furnaces" (1933) and "Glassto-Metal Seals" (1947). Dr. Partridge has been a vice-president of the Society of Glass Technology and was honorary general secretary during 1946-49.

\section{New Foreign Members of the Royal Society}

THE following have been elected foreign members of the Royal Society: Kai Ulric Linderstrøm-Lang (Copenhagen), distinguished for his contribution to protein chemistry and for his pioneer development of ultra micro-techniques for the biochemical study of the localization of enzymes in tissue cells; Hans Pettersson (Göteborg), distinguished for his researches in oceanography; Robert Burns Woodward (Cambridge, U.S.A.), distinguished for his investigations in organic chemistry, especially on the synthesis of important natural products such as quinine, cortisone and antibiotics; Fritz Zernike (Gröningen), dis- 